\title{
Estado de juízes: aquele jardim, no Inferno*
}

\section{State of judges: that garden, in Hell}

\author{
Eros Roberto Grau**
}

A mulher tem direito sobre o corpo. Mas qual corpo? Aquele que gesta no seu ela pode matar?

José Antonio Brenner

É proibido arrancar flores, mas podem ser suprimidos os botões antes de se abrirem.

(placa em um jardim no Inferno)

\section{RESUMO}

O artigo contesta, com base na lei, decisões judiciais que absolveram casos de aborto e, assim, desrespeitaram e invadiram questões do Legislativo e da Constituição. O autor questiona, em específico, a legalização ou absolvição do aborto em caso de feto anencéfalo.

* Artigo recebido em 26 de dezembro de 2016 e aprovado em 26 de janeiro de 2017. DOI: http:// dx.doi.org/10.12660/rda.v274.2017.68742.

** Supremo Tribunal Federal, Brasília, DF, Brasil. E-mail: contato@erosgrau.com. Advogado. Ex-ministro do Supremo Tribunal Federal. 


\section{PALAVRAS-CHAVE}

Judiciário - aborto - feto anencéfalo - legalização - direito do feto

\section{ABSTRACT}

The article questions, based on law, some court decisions that absorbed abortion cases and, thus, disrespected and invaded legislative and constitutional matters. The author questions, specifically, the legalization or absolution of the abortion in cases of Anencephalic fetus.

\section{KEYWORDS}

Judiciary - abortion - anencephalic fetus - legalization - fetal rights

01. A Constituição do Brasil afirma a independência e harmonia entre Legislativo, Executivo e Judiciário - artigo $2^{\mathrm{o}}-$, o que supõe que cada um dos três Poderes se limite a exercer as funções que lhe cabem. Daí que o Judiciário não pode legislar. Essa é uma prerrogativa do Legislativo.

Não obstante seja assim, a invasão da competência do Legislativo pelo Judiciário é, atualmente, alarmante. Passamos a viver não mais sob um estado de direito, porém submissos a um estado de juízes. A apropriação, pelo Judiciário, do poder de fazer leis e alterá-las é estarrecedora. Ninguém negará que os juízes hão de ser independentes, mas - nas democracias - nos termos e no quadro da Constituição e das leis, garantindo a sua aplicação. Não podem, em hipótese nenhuma, ir além. A Constituição lhes impõe o dever de declarar sua eventual inconstitucionalidade, mas a substituição dos preceitos declarados inconstitucionais por outros incumbe exclusivamente ao Legislativo.

Desafortunadamente, no entanto, juízes de primeira instância - especialmente os tribunais - em nossos dias seguidamente se apropriam da função de legislar. Glosando uma canção de Roberto Carlos, os juízes de hoje em dia, sem saber o que é direito, fazem suas próprias leis! ${ }^{1}$

1 Tribunais de hoje em dia são terríveis. Caminhando por alguns votos veremos, por exemplo, que há quem afirme que a Constituição não considera existir vida no embrião, o que equivale a afirmar-se a inconstitucionalidade de inúmeros preceitos do Código Civil! A decisão lavrada na ADI 3.510 pelo Supremo Tribunal Federal, o caso das células-tronco, foi festejada como aurora de um novo tempo, celebração solidária da vida e da liberdade! Palavras fluem livremente, procurando encantar, sendo porém insuficientes para esconder, no caso do aborto, a celebração da morte. Pois mesmo a geração de um anencéfalo é consequência de um ato de 
02. Isto se torna evidente quando nos damos conta, por exemplo, de que o Supremo Tribunal Federal vem tomando decisões no sentido de descriminalizar o aborto.

O artigo 128 do Código Penal estabelece que "não se pune o aborto praticado por médico: I - se não há outro meio de salvar a vida da gestante; e II - se a gravidez resulta de estupro e o aborto é precedido de consentimento da gestante ou, quando incapaz, de seu representante legal". Fora dessas hipóteses o aborto é crime. Isso é o que diz a lei, com todas as letras.

Não obstante, em abril de 2012 o Supremo Tribunal Federal declarou, na $\mathrm{ADPF} 54$, a inconstitucionalidade da interpretação segundo a qual a interrupção da gravidez de feto anencéfalo é crime. Dizendo-o em outros termos, declarou que, embora a lei estipule que o aborto de anencéfalo é um crime, nós (o STF) achamos e decidimos que não é!

03. Agora vai além. Alegando que a criminalização do aborto no primeiro trimestre de gravidez viola os direitos fundamentais da mulher [voto do relator], descriminalizou-o. Em outros termos, a interrupção da gravidez até o terceiro mês de gestação deixa de ser crime! Uma decisão escancaradamente absurda.

Uma agressão à Constituição, pois ele (o STF) se arroga poder de legislar. Na ADPF 54 acrescentou mais uma hipótese ao artigo 128 do Código Penal o aborto de anencéfalo - e agora outra mais, a do aborto praticado nos três primeiros meses de gestação.

04. Há alguns anos - época em que estive a judicar nesse tribunal elaborei um voto que lastimavelmente não tive oportunidade de proferir, para o julgamento da ADPF 54. Isso porque os autos foram incluídos em pauta após a data em que dele me retirei, aposentado pela idade. Mas não terá sido em vão, pois de alguns trechos seus agora irei me valer, na sequência deste meu grito.

Tudo quanto nele eu diria cabe qual u'a luva ao aborto praticado nos três primeiros meses de gestação, questão à qual adiante retornarei.

05. O direito romano não exigia a viabilidade como condição de capacidade das pessoas naturais, qual demonstrou um notável juiz do STF, Edmundo Lins. $^{2}$

busca de prazer. Quem o busca, usando de liberdade para tanto, há de ser responsável pelas consequências, inclusive essa. Ouso gritar que a beleza, em todas as suas formas, mesmo em palavras desdobradas em poemas, havia de ser proibida a quem proclame desafeto pela vida.

2 LINS, Admundo. Theoria da viabilidade. In: ___. Estudos juridicos na cathedra e na judicatura. Rio de Janeiro: A. Coelho Branco Fo, 1935. p. 57 e ss. 
Ainda que o contrário disso seja dito por aí, o processo da civilização vem lentamente banindo desumanidades, de sorte que, entre nós, desde a vigência do primeiro Código Civil, certas patologias deixaram de consubstanciar causa de recusa à capacidade jurídica do recém-nascido.

A proteção conferida ao nascituro era já assegurada pelo direito justinianeu. No Brasil, prevista nas Ordenações Filipinas ${ }^{3}$ e Afonsinas, ${ }^{4}$ foi definitiva e expressamente consagrada no artigo $4^{\circ}$ do Código Civil de 1916. Recorro a Clóvis Bevilacqua: "Realmente, se o nascituro é considerado sujeito de direito, se a lei civil the confere um curador, se a lei criminal o protege cominando penas contra a provocação do aborto, a lógica exige que se lhe reconheça o caráter de pessoa".

06. O nascituro não somente é protegido pela ordem jurídica, sua dignidade humana preexistindo ao fato do nascimento, mas é titular de direitos adquiridos. Rememoro lição de Pontes de Miranda:6 "No intervalo entre a concepção e o nascimento, os direitos, que se constituíram, têm sujeito, apenas não se sabe qual seja".

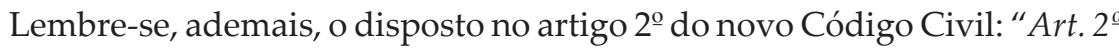
A personalidade civil da pessoa começa do nascimento com vida; mas a lei põe a salvo, desde a concepção, os direitos do nascituro".

Não há, pois, espaço para distinções, como assinala José Neri da Silveira em belo parecer sobre o tema: "em nosso ordenamento jurídico, não se concebe distinção também entre seres humanos em desenvolvimento na fase intrauterina, ainda que se comprovem anomalias ou malformações do feto; todos enquanto se desenvolvem no útero materno são protegidos, em sua vida e dignidade humana, pela Constituição e leis".

Trata-se de seres humanos que podem receber doações [artigo 542 do Código Civil], figurar em disposições testamentárias [artigo 1.799 do Código Civil] e mesmo ser adotados [artigo 1.621 do Código Civil], de modo que a frustração da sua existência fora do útero materno, por ato do homem, merece vigorosa repulsa pela ordem jurídica.

07. Há quem argumente com a inviabilidade do nascituro portador de anencefalia. Pretende-se justificar, destarte, a prática do aborto de ser humano

\footnotetext{
Livro III, Título 18, §7.

Livro III, Título 36, §7.

5 Citado por SANTOS, Carvalho. Código Civil brasileiro interpretado. São Paulo: Freitas Bastos, 1956. v. I, p. 246.

6 BEVILACQUA, Clóvis. Tratado de direito privado. Campinas: Bookseller, 1999. t. I, p. 234.
} 
que não sobreviverá por muito tempo, segundo se afirma, fora do útero materno.

Alguns ordenamentos efetivamente tomam o nascimento viável como requisito da aquisição de direitos, qual o Código Civil francês, em seus artigos $725^{7}$ e $906,{ }^{8}$ aliás vigorosamente rechaçados por Velez Sarsfield. ${ }^{9}$

O direito brasileiro não adota, no entanto, a viabilidade do nascituro para proteção de seus direitos. Permanece atual, e significativa, a doutrina de Teixeira de Freitas, ${ }^{10}$ em comentário ao artigo 221 do Esboço: "Não concebo que haja ente com suscetibilidade de adquirir direitos, sem que haja pessoa. Se se atribui direitos às pessoas por nascer, posto que como diz Savigny, em uma ordem especial de fatos; se os nascituros são representados no caso do art. 54, dando-se-lhes o Curador, que se tem chamado Curador o ventre; é forçoso concluir, que já existem, e que são pessoas; pois o nada não se representa".$^{11}$

08. A interpretação/aplicação do direito pressupõe a plena compreensão da realidade pelo intérprete. Mas este não é autorizado, pena de faltar aos seus deveres, a decidir segundo qualquer outra lógica que não a jurídica. Dela não pode se afastar, seja para ceder à ciência, seja para adotar valores de ética religiosa. Há de decidir no quadro da ordem jurídica, estrita e restritamente.

E não há como, na moldura da lógica jurídica, conceber o feto com res. A esse respeito, observa Jérome Lejeune, ${ }^{12}$ em vernáculo: "Ainda não vi um cientista chegar à opinião de que se trata de um bem móvel [...]. Nunca ouvi um dos meus colegas - as nossas opiniões divergem em numerosos assuntos - dizer-me ou

7 “Art. 725. Pour succéder, il faut exister à l'instant de l'ouverture de la succession ou, ayant déjà été conçu, naître viable.

Peut succéder celui dont l'absence est présumée selon l'article 112".

8 "Art. 906. Pour être capable de recevoir entre vifs, il suffit d'être conçu au moment de la donation.

Pour être capable de recevoir par testament, il suffit d'être conçu à l'époque du décès du testateur. Néanmoins, la donation ou le testament n'auront leur effet qu'autant que l'enfant sera né viable".

9 SARSFIELD, Velez. Código Civil de la República Argentina con las notas de Velez Sarsfield. Buenos Aires, Victor P. de Zavalía, 1969. p. 34. Velez Sarsfield sustenta que esta doutrina "no tiene ningún fundamento, pues es contraria a los principios generales sobre la capacidad de derecho inherente al hecho de la existencia de una criatura humana, sin consideración alguna a la mayor o menor duración que pueda tener esa existencia. Este es el derecho general, y no se comprende qué motivo haya para introducir una restricción respecto al recién nacido. La muerte que sobrevenga puede provenir de circunstancias exteriores y no de la no viabilidad".

10 FREITAS, Teixeira de. Esboço. Rio de Janeiro: Serviço de Documentação do Ministério da Justiça e Negócios Interiores. 1952. v. I, p. 135.

11 No Esboço (op. cit., p. 137-138) de Teixeira de Freitas encontra-se o artigo 224, cujo teor é o seguinte: "Art. 224. Também não importará, [sic] que os nascidos com vida tenham impossibilidade de prolongá-la, e que pereçam logo depois do nascimento, ou por nascerem antes do tempo, ou por qualquer vício de organização interna".

12 LEJEUNE, Jérome. L'embrione segno di contradizione. Edizioni Orizzonte Medico, 1992. p. 80. 
dizer aos outros que um embrião congelado seja propriedade de alguém ou que possa ser vendido ou destruído, como se fosse uma mercadoria". ${ }^{13}$

09. Nenhum, entre a hierarquia dos juízes de nossa terra, em tese negaria aplicação do disposto no artigo 123 do Código Penal ${ }^{14}$ - que tipifica o crime de infanticídio - à mulher que matasse, sob a influência do estado puerperal, o próprio filho anencéfalo, durante o parto ou logo após, sujeitando-a a pena de detenção, de dois a seis anos. Vejam-se, a respeito, os comentários de Teixeira de Freitas ao artigo 224 do Esboço. ${ }^{15}$

Note-se que ao texto do tipo penal - "Matar, sob a influência do estado puerperal, o próprio filho, durante o parto ou logo após: [p]ena - detenção, de dois a seis anos" - acrescentei unicamente o vocábulo anencéfalo.

Ora, se o filho anencéfalo morto pela mãe sob a influência do estado puerperal é ser vivo, por que não o seria o feto, que - repito - pode receber doações, figurar em disposições testamentárias e mesmo ser adotado?

Que lógica é esta que toma como ser, que considera ser alguém - e não res - o anencéfalo vítima de infanticídio, mas atribui ao feto que lhe corresponde o caráter de coisa ou de "algo".

Jamais me cansarei de repetir que juízes podem e devem decidir sem exceder a ordem jurídica, sem dela, contudo, se afastarem.

10. Ademais, há ainda quem diga que a medicina dá como certa a morte do bebê anencéfalo fora do útero materno em 100\% dos casos, cerca de $65 \%$ das crianças morrendo ainda no ventre da mãe.

Não é, porém, necessária qualquer certeza médica para afirmar-se que a morte é certa em 100\% dos casos de vida extrauterina... Ela é tão certa para o feto anencéfalo como para qualquer um de nós. Ademais, se há morte é porque, em algum momento, houve vida, ainda que no interior do útero materno, a partir da fecundação.

Outrossim, a estatística noticia que 35\% dos fetos anencéfalos vencem o período de gestação e chegam ao parto, momento que lhes é garantido à luz da Constituição do Brasil e da legislação infraconstitucional.

13 No original: "Non ho ancora visto una persona di scienza giungere all'opinione che si tratta di un bene mobile [...] Non ho mai sentito uno dei miei colleghi - le nostre opinioni divergono su numerosi argomenti - dirmi o dire ad altri che un embrione congelato sia la proprietà di qualcuno, che possa essere venduto o liquidato come un bene".

14 "Matar, sob a influência do estado puerperal, o próprio filho, durante o parto ou logo após: Pena - detenção, de dois a seis anos".

15 Teixeira de Freitas, Esboço, op. cit., p. 137-138. 
O que a estatística não diz é que a certeza do diagnóstico médico da anencefalia não é absoluta, de modo que a prevenção do erro, mesmo culposo, não será sempre possível. O que dizer, então, do erro doloso? A quantas não chegará, em seu dinamismo, o moinho satânico de que dizia Karl Polanyi? ${ }^{16}$

Causa mesmo enorme espanto a ideia de que se possa promover defesa do aborto sem interesse econômico. Estou plenamente convencido de que, embora aludindo à defesa de apregoados direitos da mulher, o que se pretende é a migração da sua prática do universo da ilicitude penal para o campo da exploração da atividade econômica. Em termos diretos e incisivos, para o mercado.

11. O feto faz parte do gênero humano, é uma parcela da humanidade. Há, nele, processo vital em curso. É o que é porque abrigado em um útero. O útero é a morada da vida. Nele se dão os momentos anteriores ao nascimento, mas de vida já.

Daí que a proteção da sua dignidade é garantida pela Constituição. É verdade que sua autonomia se manifesta de maneira especial, na medida em que a única opção que detém é nascer. Mas é autonomia. Não há nenhuma dúvida, pois, a respeito do fato de que há, no aborto, destruição da vida.

Anencéfalo ou não, um filho morto sob a influência do estado puerperal é um ser vivo. Sua morte pela mãe consubstancia um homicídio. Então, pergunto: por que não seria criminoso o assassinato de um feto anencéfalo, que - repito mais uma vez - pode receber doações [artigo 542 do Código Civil], figurar em disposições testamentárias [artigo 1.799 do Código Civil] e mesmo ser adotado [artigo 1.621 do Código Civil]?

Mais grave ainda, terrível e assustador, é o que agora - escrevo este texto em dezembro de 2016 - o STF pretende legalizar, o assassinato de fetos sadios, mediante aborto, nos primeiros três meses de gestação.

12. Uma breve história, por fim. Um homem simples, do campo, ${ }^{17}$ ouvindo algumas pessoas discutirem em torno de ser ou não perigosa, para a mãe, a interrupção da gravidez no segundo e no terceiro mês de gestação, perguntou-lhes, ingenuamente, se não seria melhor deixar nascer a criança e matá-la, no primeiro momento de vida fora da mãe...

16 POLANYI, Karl. A grande transformação: as origens da nossa época. Tradução portuguesa de Fanny Wrobel. 2. ed. Rio de Janeiro: Campus, 2000.

17 O homem do campo tem o tempo - diz um poema meu -

De apascentar seus ódios e tormentos.

O homem do campo tem o tempo

De decompor a palavra maravilha

Em mar, ave e ilha. 
Um horror! A vida é maravilhosa, mas - lastimavelmente - juízes sem preconceitos, sem saberem o que é o direito, fazem suas próprias leis...

\section{Referências}

FREITAS, Teixeira de. Esboço. Rio de Janeiro: Serviço de Documentação do Ministério da Justiça e Negócios Interiores, 1952.

LEJEUNE, Jérome. L'embrione segno di contradizione. Edizioni Orizzonte Medico, 1992.

LINS, Edmundo. Theoria da viabilidade. In: . Estudos juridicos na cathedra e na judicatura. Rio de Janeiro: A. Coelho Branco Fo, 1935.

MIRANDA, Pontes. Tratado de direito privado. Campinas: Bookseller, 1999. t. I. POLANYI, Karl. A grande transformação: as origens da nossa época. Tradução portuguesa de Fanny Wrobel. 2. ed. Rio de Janeiro: Campus, 2000.

SANTOS, Carvalho. Código Civil brasileiro interpretado. São Paulo: Freitas Bastos, 1956. v. I.

SARSFIELD, Velez. Código Civil de la República Argentina con las notas de Velez Sarsfield. Buenos Aires: Victor P. de Zavalía, 1969. 